\title{
KEANEKARAGAMAN JENIS SERTA POLA DISTRIBUSI BIVALVIA DI PERAIRAN PULAU SIANTAN KABUPATEN ANAMBAS PROVINSI KEPULAUAN RIAU
}

\author{
Lani Puspita $^{1}$ dan Titin Nur Istikomah ${ }^{2}$ \\ ${ }^{12}$ Program Studi Pendidikan Biologi FKIP Universitas Riau Kepulauan \\ Koresponen : lani@unrika.ac.id
}

\begin{abstract}
ABSTRAK
Bivalvia adalah salah satu kelas dari Filum Moluska yang umum dijumpai di perairan pesisir dan memiliki banyak manfaat baik secara ekologi maupun ekonomi. Penelitian ini dilakukan di Perairan Pulau Siantan Kabupaten Kepulauan Anambas dan bertujuan untuk menganalisis keanekaragaman jenis serta pola distribusi Bivalvia di lokasi tersebut. Pengambilan contoh dilaksanakan pada minggu keempat Maret hingga minggu ketiga April 2012 di pantai berpasir Tg. Momong, pantai berpasir Pulau Termawan, pantai berpasir lumpur Air Asuk, dan pantai berlumpur Air Nangak. Variabel yang dianalisis meliputi Tingkat Keanekaragaman Jenis yang dihitung dengan Indeks Shannon-Wiener (H'), Tingkat Keseragaman Jenis yang dihitung dengan Indeks Evennes (E), Indeks Dominansi Jenis yang dihitung dengan Indeks Simpson (D), dan Pola Distribusi yang dihitung dengan Indeks Morisita. Selain itu juga dilakukan Uji Perbandingan 2 Populasi dengan Uji-T untuk membandingkan total populasi Bivalvia serta jumlah jenis Bivalvia antara Stasiun Sampling Tg. Momong dan Pulau Termawan.

Hasil identifikasi jenis memberikan hasil bahwa di lokasi studi ditemukan 13 famili dan 24 spesies Bivalvia. Keanekaragaman jenis Bivalvia di pantai berpasir tergolong tinggi sedangkan di pantai berlumpur tergolong sedang hingga tinggi. Keseragaman jenis Bivalvia di seluruh jenis pantai tergolong tinggi dan dominansi jenisnya tergolong rendah. Hasil analisis pola distribusi menunjukkan bahwa seluruh family Bivalvia di seluruh stasiun pengamatan memiliki pola distribusi berkelompok. Hasil analisis Uji-T menunjukkan bahwa terdapat perbedaan total populasi Bivalvia dan jumlah jenis Bivalvia antara antara Stasiun Sampling Tg. Momong dan Pulau Termawan pada selang kepercayaan $90 \%(\alpha=10 \%)$.
\end{abstract}

Kata kunci: bivalvia, pesisir, Kepulauan Anambas

\section{PENDAHULUAN}

Bivalvia mempunyai peranan yang penting dari segi ekologi maupun ekonomi. Dalam segi ekologi, larva Bivalvia merupakan makanan penting bagi hewan pemakan zooplankton di laut (Suwignyo et. al, 2005). Jenis Bivalvia yang dapat menghasilkan mutiara berkualitas contohnya adalah Pinctada margaretifera; dan Bivalvia yang biasa digunakan sebagai bahan konsumsi manusia antara lain Kerang darah (Anadara granosa), Kerang bulu (Anadara antiquata), Kerang hijau (Mylitis viridis), dan Tiram bakau (Crassotrea cucullata) (Romimohtarto, 2009 dan Nontji, 2007).

Kelimpahan dan distribusi Bivalvia dipengaruhi oleh faktor fisika-kimia lingkungan setempat, ketersediaan makanan, pemangsaan, dan kompetisi (Nybakken, 1992). Penelitian dilakukan di Pulau Siantan Kabupaten Kepulauan Anambas karena data 
dan informai mengenai keanekaragaman jenis dan pola distribusi Bivalvia di daerah tersebut masih sangat minim. Penelitian ini bertujuan untuk: (1) Mengidentifikasi jenisjenis Bivalvia di lokasi penelitian; (2) Menganalisis tingkat keanekaragaman jenis, keseragaman jenis, dan dominansi jenis Bivalvia di lokasi penelitian; dan (3) Menganalisis pola distribusi jenis Bivalvia di lokasi penelitian. Pengambilan contoh dilaksanakan pada bulan Maret 2012 di pantai berpasir Tg. Momong, pantai berpasir Pulau Termawan, pantai berpasir lumpur Air Asuk, dan pantai berlumpur Air Nangak. Analisis dilakukan secara spasial (membandingkan struktur komunitas Bivalvia antar lokasi sampling). Hasil penelitian ini diharapkan dapat bermanfaat sebagai bahan rujukan bagi berbagai pihak, seperti Dinas Perikanan dan Kelautan serta kelompok nelayan di Kabupaten Kepulauan Anambas.

\section{METODE PENELITIAN}

Penelitian ini dilaksanakan di perairan pesisir Pulau Siantan Kabupaten Kepulauan Anambas Provinsi Kepulauan Riau. Pengambilan contoh dilakukan di 4 stasiun sampling, yaitu: di pantai berpasir Tg. Momong (St. 1), pantai berpasir Pulau Termawan (St. 2), pantai berpasir lumpur Air Asuk (St. 3), dan pantai berlumpur Air Nangak (St. 4). Pada masing-masing stasiun sampling ditetapkan 3-10 plot pengamatan. Luas plot pengamatan pada St. 1 dan St. 2 yang merupakan pantai berpasir adalah $1 \mathrm{~m}^{2} /$ plot; luas plot pengamatan pada St. 3 dan St. 4 yang merupakan pantai berlumpur adalah 202,5802 $\mathrm{cm}^{2} /$ plot.

Peralatan yang digunakan pada penelitian ini adalah: (1) transek kuadrat berukuran 1 x 1 meter untuk membatasi plot pengambilan contoh di pantai berpasir, dan pipa paralon PVC berdiameter 2 inchi (luas penampang $=20,2850 \mathrm{~cm}^{2}$ ) untuk mengambil substrat di pantai berlumpur; (2) saringan kasar; (3) lup (kaca pembesar); (4) cool box; (5) lemari pendingin; (6) handy-counter; (7) rol meter; dan (8) kamera. Bahan yang digunakan adalah es dan tissue. Buku identifikasi Bivalvia yang digunakan adalah: "The Mc. Donalds Encyclopedia of Shells (Sabeli, 1991), Periplus Nature Guides of Tropical Seashells (Fiene-Severn et. al, 2000), Avertebrata Air (Suwignyo et. al, 2005), dan referensi internet (http://www.seashellhub.com).

Pengambilan contoh di pantai berpasir dilakukan dengan langkah kerja sebagai berikut: (1) Meletakkan transek kuadrat berukuran 1 x 1 meter di stasiun pengambilan 
contoh; (2) Mengorek substrat pasir hingga kedalaman $60 \mathrm{~cm}$ dan mengambil jenis-jenis bivalvia yang ditemukan; selanjutnya (3) Bivalvia yang ditemukan kemudian disimpan pada kantung plastik yang diberi label lokasi stasiun pengambilan contoh dan tanggal pengambilan contoh.

Pengambilan contoh Bivalvia pada pantai berlumpur dilakukan dengan langkah kerja sebagai berikut: (1) Mengambil substrat lumpur menggunakan alat sampling berupa pipa paralon PVC berdiameter 2 inchi (luas penampang $=20,2850 \mathrm{~cm}^{2}$ ); (2) Pipa paralon ditancapkan ke dalam substrat lumpur sehingga substrat tertahan di dalam paralon, substrat yang tertahan tersebut kemudian dimasukkan ke dalam kantung plastik contoh, dengan cara ini Bivalvia yang hidup di permukaan substrat (epifauna) dan di dalam substrat (infauna) dapat terambil.

Contoh Bivalvia diidentifikasi dengan cara membandingkan morfologi contoh Bivalvia yang ditemukan terhadap panduan yang ada di buku panduan identifikasi dan yang ada di referensi internet (http://www.seashellhub.com). Untuk membantu pengamatan morfologi Bivalvia digunakan kaca pembesar. Jumlah individu Bivalvia yang ditemukan untuk setiap spesiesnya kemudian ditabulasi dan dihitung kepadatan jenisnya.

Perhitungan kepadatan jenis dilakukan dengan rumus sebagai berikut:

$$
N_{i}=\frac{n_{i}}{A}
$$

$\mathrm{N}_{\mathrm{i}}=$ kelimpahan Bivalvia jenis ke-i (individu $/ \mathrm{m}^{2}$ )

$\mathrm{n}_{\mathrm{i}} \quad=$ jumlah total individu plankton jenis ke-i yang ditemukan (individu)

$\mathrm{A}=$ luas area pengamatan atau pengambilan sampel.

\section{Analisis Struktur Komunitas Bivalvia}

$\underline{\text { Keanekaragaman Jenis }}$

Keanekaragaman jenis dihitung dengan menghitung Indeks Keanekaragaman Jenis Shannon - Wienner (H'). Rumusnya adalah sebagai berikut:

$$
H^{\prime}=\sum\left(\frac{N_{i}}{N_{\text {total }}} \bullet \log _{2} \frac{N_{i}}{N_{\text {total }}}\right)
$$

$\mathrm{H}^{\prime}=$ Indeks Keanekaragaman Jenis Shannon - Wienner

$\mathrm{N}_{\mathrm{i}}=$ kepadatan Bivalvia jenis ke-i (individu/meter ${ }^{2}$ )

$\mathrm{N}_{\text {total }}=$ kepadatan seluruh jenis Bivalvia yang teridentifikasi (individu/meter ${ }^{2}$ )

$\log _{2}=$ logaritma basis dua 
Kisaran nilai:

$$
\begin{array}{ll}
0 \leq \mathrm{H}^{\prime}<1 & \text { tingkat keanekaragaman jenis rendah } \\
1 \leq \mathrm{H}^{\prime}<3 & \text { tingkat keanekaragaman jenis sedang } \\
\mathrm{H}^{\prime} \geq 3 & \text { tingkat keanekaragaman jenis tinggi }
\end{array}
$$

\section{$\underline{\text { Keseragaman Jenis }}$}

Keseragaman jenis dihitung dengan menghitung Indeks Keseragaman Jenis Evenness (E).

Rumusnya adalah sebagai berikut:

$$
E=\frac{H^{\prime}}{\log _{2} S}
$$

$\mathrm{E}=$ Indeks Keseragaman Evenness

$\mathrm{H}^{\prime}=$ Indeks keanekaragaman Shannon - Wienner

$\log _{2}=$ logaritma basis 2

$\mathrm{S}=$ jumlah species Bivalvia yang ditemukan

Kisaran nilai:

$$
\begin{array}{ll}
0 \leq \mathrm{E}<0,3 & \text { tingkat keseragaman jenis rendah } \\
0,3 \leq \mathrm{E}<0,6 & \text { tingkat keseragaman jenis sedang } \\
0,6 \leq \mathrm{E}<1,0 & \text { tingkat keseragaman jenis tinggi }
\end{array}
$$

\section{Dominansi Jenis}

Dominansi jenis dihitung dengan menghitung Indeks Dominansi Simpson. Rumusnya adalah sebagai berikut:

$$
D=\sum\left(\frac{N_{i}}{N_{\text {total }}}\right)^{2}
$$

$\mathrm{D}=$ indeks dominansi simpson

$\mathrm{N}_{\mathrm{i}}=$ kepadatan Bivalvia jenis ke-i (individu $/$ meter $^{2}$ )

$\mathrm{N}_{\text {total }}=$ kepadatan seluruh jenis Bivalvia yang teridentifikasi (individu/meter ${ }^{2}$ )

Kisaran nilai:

$0 \leq \mathrm{D}<0,3 \quad$ tingkat dominansi jenis rendah

$0,3 \leq \mathrm{D}<0,6 \quad$ tingkat dominansi jenis sedang

$0,6 \leq \mathrm{E}<1,0 \quad$ tingkat dominansi jenis tinggi

\section{$\underline{\text { Pola Distribusi }}$}

Pola Distribusi dihitung dengan rumus perhitungan Indeks Morisita di masing-masing stasiun sampling. Pola distribusi dihitung untuk masing-masing famili dalam Kelas Bivalvia. 


$$
\operatorname{Id}=\frac{N\left(\sum x^{2}-\sum X\right)}{\left.\left(\sum X\right)^{2}-\sum X\right)}
$$

Keterangan:

$\mathrm{N}=$ jumlah plot (transek)

$\mathrm{X}=$ jumlah individu pada Setiap Plot

Kisaran nilai:

$\mathrm{Id}=1:$ penyebaran acak

Id $>1$ : penyebaran berkelompok

Id $<0$ : penyebaran seragam sempurna

\section{Analisis Data secara Statistika untuk Membandingkan 2 Populasi}

Perbandingan 2 populasi secara statistika dilakukan untuk mengetahui ada/tidaknya perbedaan antara total populasi Bivalvia serta jumlah jenis Bivalvia antara stasiun sampling pantai berpasir Tg. Momong (yang merupakan perairan tertutup) dan stasiun sampling pantai berpasir Pulau Termawan (yang merupakan perairan terbuka). Sebelum dilakukan perbandingan, terlebih dahulu dilakukan uji distribusi data, apabila data tersebar normal maka pengolahan data dilakukan secara statistika parametrik dengan Uji-T, namun apabila data tidak tersebar normal maka pengolahan data dilakukan secara statistika nonparametrik dengan Uji Mann-Whitney.

\section{HASIL DAN PEMBAHASAN}

Stasiun $1 \mathrm{Tg}$. Momong merupakan pantai berpasir yang berada di perairan terbuka. Pada stasiun pengamatan tersebut dijumpai 14 spesies bivalvia. Spesies yang paling banyak dijumpai adalah Tellina disculus dengan kepadatan relatif 32\%, selanjutnya adalah Anadara granosa dengan kepadatan relatif 13\%, Anadara antiquata dengan kepadatan relatif $12 \%$, dan Lunulicardia retusa $11 \%$. Spesies lainnya memiliki kepadatan relatif masing-masing di bawah $10 \%$. Spesies yang memiliki kepadatan relatif paling sedikit adalah Trachycardium enode, Chama lazarus, dan Gari cosrulata (masing-masing memiliki kepadatan relatif 1\%). Besarnya kepadatan relatif Tellina disculus disebabkan karena substrat berpasir dengan sedikit lumpur merupakan habitat yang sangat cocok bagi kehidupan Tellina disculus. 


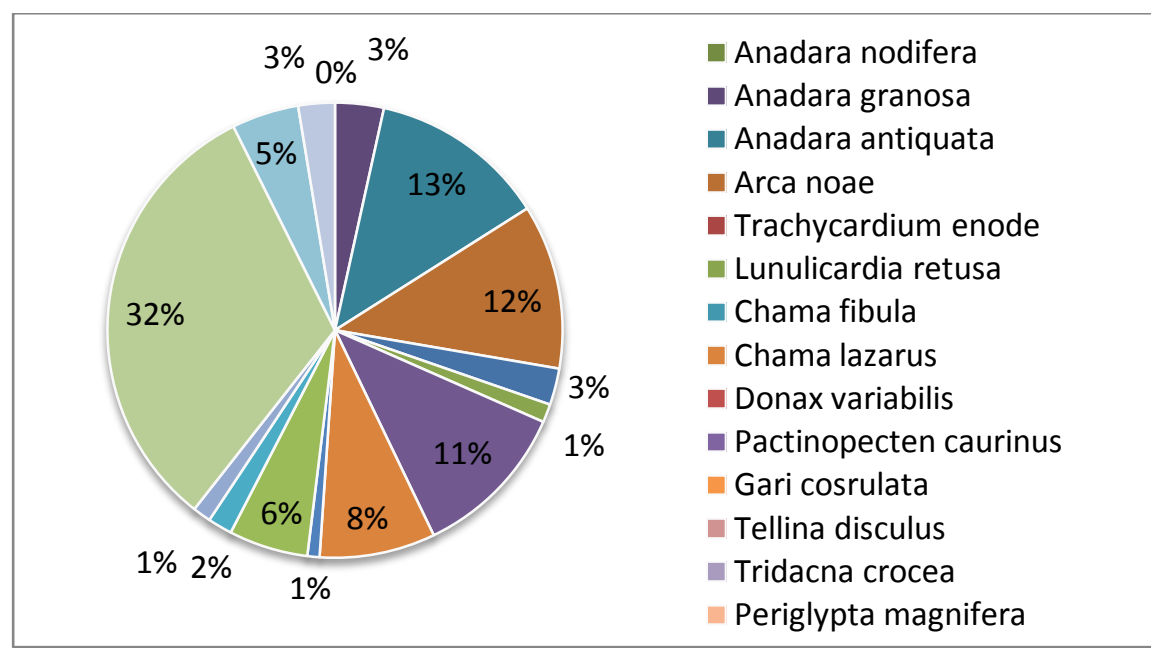

Gambar 2. Komposisi Jenis Bivalvia pada Pantai Berpasir Tanjung Momong

Pada Stasiun 2 (Pantai Berpasir Pulau Termawan), ditemukan 16 spesies bivalvia. Spesies yang ditemukan dengan kepadatan relatif terbanyak adalah Anadara antiquata (27\%), diikuti oleh Lunulicardia retusa (24\%), dan Tellina disculus (16\%). Spesies lainnya ditemukan dengan kepadatan relatif masing-masing dibawah 10\%. Spesies-spesies yang hanya ditemukan dengan kepadatan relatif $1 \%$ adalah Arca noae, Chama fibula, Chama lazarus, Pactinopecten, Tellina staurella, Hippopus hippopus, Tapes aureus, Periglypta magnifera, dan Chione californiensis.

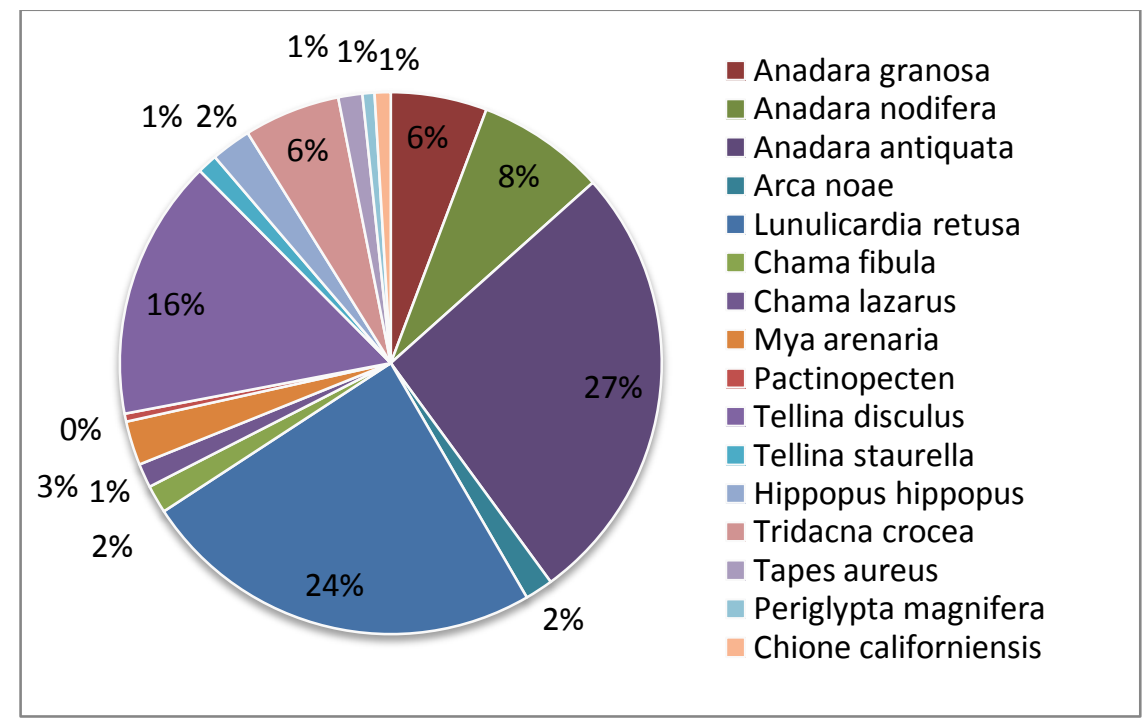

Gambar 3. Komposisi Jenis Bivalvia pada Pantai Berpasir Pulau Termawan

Di Pantai Berpasir Lumpur Air Asuk (Stasiun 3) dijumpai 15 spesies bivalvia. Spesies yang paling banyak dijumpai adalah Anadara nodifera (36\%), diikuti oleh Tellina disculus (13\%), dan Pteria sp. (10\%). Spesies lainnya ditemukan dengan kepadatan relatif 
kurang dari 10\%; dan spesies yang memiliki kepadatan relatif paling sedikit adalah Chione californiensis (hanya 1\%). Tingginya kepadatan relatif Anadara nodifera dan A. granosa di stasiun ini disebabkan karena pada stasiun ini terdapat vegetasi lamun yang luas yang mendukung pertumbuhan bivalvia karena masih berlimpahnya bahan organik.

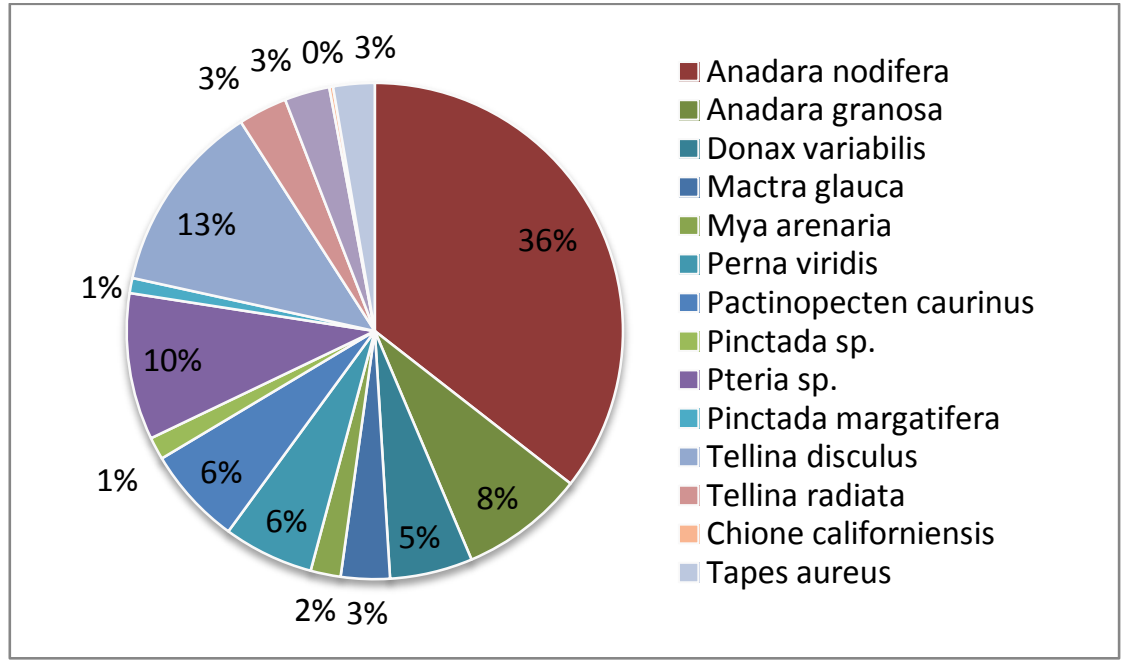

Gambar 4. Komposisi Jenis Bivalvia pada Pantai Berpasir Pulau Termawan

Di Pantai Berlumpur Air Nangak (Stasiun 4) ditemukan 11 spesies bivalvia. Spesies yang paling banyak ditemukan di lokasi ini adalah Anadara nodifera dengan kepadatan relatif 40\%, diikuti oleh Anadara granosa (26\%) dan Tellina disculus (16\%). Spesies bivalvia lainnya ditemukan dengan kepadatan relatif masing-masing di bawah 10\%. Spesies bivalvia yang paling sedikit dijumpai (memiliki kepadatan relatif 1\%) adalah Arca noae dan Lunulicardia retusa. Tingginya komposisi Anadara nodifera dan A. granosa di Stasiun 4 ini disebabkan karena lokasi ini merupakan pantai berlumpur yang memiliki kandungan organik cukup tinggi dan vegetasi mangrove yang luas.

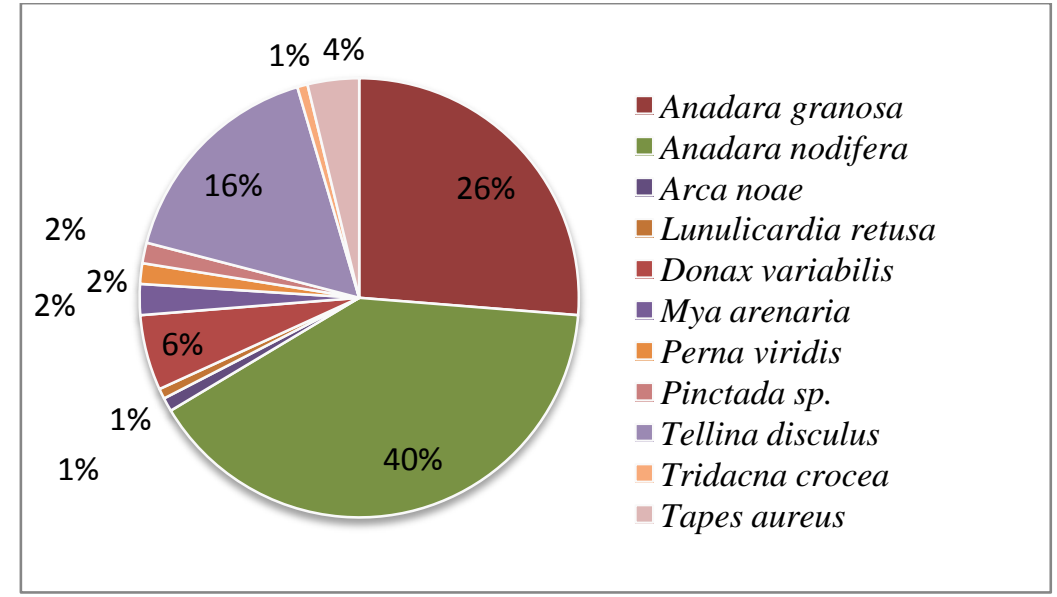

Gambar 5. Komposisi Jenis Bivalvia pada Pantai Berpasir Pulau Termawan 
Nilai Indeks Keanekaragaman Jenis Shannon-Wiener (H'), Indeks Keseragaman Jenis Evennes (E), dan Indeks Dominansi Simpson (D) adalah parameter-parameter yang menunjukkan struktur komunitas. Pada tabel berikut disajikan nilai total populasi bivalvia (ind $/ \mathrm{m}^{2}$ ), jumlah jenis (spesies), nilai indeks H', nilai indeks E, dan nilai indeks D dari masing-masing stasiun pengamatan.

Tabel 1. Total Populasi, Jumlah Jenis, Nilai Indeks Keanekaragaman, Nilai Indeks Keseragaman, dan Nilai Indeks Dominansi Bivalvia pada Masing-Masing Stasiun Pengamatan.

\begin{tabular}{llccccc}
\hline No. & \multicolumn{1}{c}{ Stasiun Sampling } & $\begin{array}{c}\mathbf{\Sigma} \text { Total } \\
\text { Populasi } \\
\left(\mathbf{I n d} / \mathbf{m}^{2}\right)\end{array}$ & $\begin{array}{c}\text { Jumlah } \\
\text { Jenis }\end{array}$ & $\begin{array}{c}\text { Nilai } \\
\text { Indeks H' }\end{array}$ & $\begin{array}{c}\text { Nilai } \\
\text { Indeks E }\end{array}$ & $\begin{array}{c}\text { Nilai Indeks } \\
\text { D }\end{array}$ \\
\hline 1. & $\begin{array}{l}\text { Pantai Berpasir Tg. } \\
\text { Momong (St. 1) }\end{array}$ & 77 & 14 & 3,168 & 0,832 & 0,154 \\
2. $\quad \begin{array}{l}\text { Pantai Berpasir Pulau } \\
\text { Temawan (St. 2) }\end{array}$ & 51 & 16 & 3,314 & 0,829 & 0,139 \\
3. & $\begin{array}{l}\text { Pantai Berpasir Lumpur Air } \\
\text { Asuk (St. 3) }\end{array}$ & 2010 & 15 & 3,138 & 0,803 & 0,172 \\
4. & $\begin{array}{l}\text { Pantai Berlumpur Air } \\
\text { Nangak (St. 4) }\end{array}$ & 1955 & 11 & 2,359 & 0,682 & 0,262 \\
\hline
\end{tabular}

Pada Tabel 1 dapat dilihat bahwa Pantai Berpasir Lumpur Air Asuk dan Pantai Berlumpur Air Nangak memiliki kepadatan total paling tinggi; hal ini disebabkan oleh susbtrat dasar perairan yang banyak mengandung lumpur. Dilihat dari jumlah spesies yang ditemukan, Stasiun 2 memiliki jumlah spesies paling tinggi dan Spesis 4 memiliki jumlah spesies paling rendah. Jumlah spesies paling rendah yang dijumpai pada Stasiun 1 disebabkan karena diperlukan pola adaptasi khusus bagi bivalvia untuk hidup di substrat berlumpur yang umumnya memiliki kandungan oksigen lebih rendah daripada substrat berpasir. Dari keempat stasiun pengamatan yang diteliti, Stasiun 1, 2, dan 3 memiliki tingkat keanekaragaman jenis bivalvia yang tinggi (karena nilai indeks di atas 3), tingkat keseragaman jenis yang tinggi (karena nilai indeks mendekati 1), dan tingkat dominansi yang rendah (karena nilai indeks mendekati 0). Kondisi ini menunjukkan komunitas yang stabil karena komunitas terdiri dari banyak spesies yang memiliki kekuatan seragam dan tidak ada yang mendominasi. Pada Stasiun 4 tingkat keanekaragaman jenis tergolong sedang namun nilai indeksnya masih di atas 2, tingkat keseragaman jenis masih tergolong sedang, dan tingkat dominansi jenis masih tergolong rendah. Nilai indeks keanekaragaman jenis $\left(H^{\prime}\right)$ yang masih di atas 2 untuk seluruh stasiun pengamatan menunjukkan bahwa 
kondisi kualitas lingkungan di Perairan Pulau Siantan Kabupaten Anambas masih baik. Hasil perhitungan Indeks Morisita untuk setiap famili bivalvia di masing-masing stasiun pengamatan menunjukkan bahwa seluruh famili bivalvia hidup dengan pola distribusi berkelompok. Hasil perhitungan Indeks Morisita disajikan pada Tabel 2 sampai dengan Tabel 5. Indeks distribusi yang berkelompok disebabkan Bivalvia tersebut memilih hidup pada habitat yang paling sesuai di dasar perairan, baik sesuai dengan faktor fisika-kimia perairan maupun factor tersedianya makanan.

Tabel 2. Nilai Indeks Morisita pada Pantai Berpasir Tanjung Momong

\begin{tabular}{clcc}
\hline NO. & \multicolumn{1}{c}{ FAMILI BIVALVIA } & INDEKS MORISITA & KETERANGAN \\
\hline 1 & Famili Archidae & 1,489 & Berkelompok \\
2 & Famili Cardidae & 1,759 & Berkelompok \\
3 & Famili Chamidae & 0,943 & Berkelompok \\
4 & Famili Donacidae & 3 & Berkelompok \\
5 & Famili Pectinidae & 3 & Berkelompok \\
6 & Famili Psammobiidae & 3 & Berkelompok \\
7 & Famili Tellinidae & 1,550 & Berkelompok \\
8 & Famili Tridacnidae & 2,018 & Berkelompok \\
9 & Famili Veneridae & 3 & Berkelompok \\
\hline
\end{tabular}

Tabel 3. Nilai Indeks Morisita pada Pantai Berpasir Pantai Termawan

\begin{tabular}{clcc}
\hline NO. & \multicolumn{1}{c}{ FAMILI BIVALVIA } & INDEKS MORISITA & KETERANGAN \\
\hline 1 & Famil Archidae & 1,115 & Berkelompok \\
2 & Famili Cardidae & 1,202 & Berkelompok \\
3 & Famili Chamidae & 3,462 & Berkelompok \\
4 & Famili Myidae & 4,909 & Berkelompok \\
5 & Famili Pectinidae & 10 & Berkelompok \\
6 & Famili Tellinidae & 1,201 & Berkelompok \\
7 & Famili Tridacnidae & 1,426 & Berkelompok \\
8 & Famili Veneridae & 2,179 & Berkelompok \\
\hline
\end{tabular}

Tabel 4. Nilai Indeks Morisita pada Pantai Berpasir Lumpur Air Asuk

\begin{tabular}{|c|c|c|c|}
\hline NO. & FAMILI BIVALVIA & INDEKS MORISITA & KETERANGAN \\
\hline 1 & Famili Archidae & 1,090 & Berkelompok \\
\hline 2 & Famili Donacidae & 1,852 & Berkelompok \\
\hline 3 & Famili Mactridae & 3,837 & Berkelompok \\
\hline 4 & Famili Myidae & 4,047 & Berkelompok \\
\hline 5 & Famili Mytilidae & 2,007 & Berkelompok \\
\hline 6 & Famili Pectinidae & 2,094 & Berkelompok \\
\hline
\end{tabular}




\begin{tabular}{clcc}
\hline NO. & \multicolumn{1}{c}{ FAMILI BIVALVIA } & INDEKS MORISITA & KETERANGAN \\
\hline 7 & Famili Pteriidae & 1,500 & Berkelompok \\
8 & Famili Tellinidae & 1,658 & Berkelompok \\
9 & Famili Tridacnidae & 2,905 & Berkelompok \\
10 & Famili Veneridae & 3,461 & Berkelompok \\
\hline
\end{tabular}

Tabel 5. Nilai Indeks Morisita pada Pantai Berlumpur Air Nangak

\begin{tabular}{clcc}
\hline NO. & \multicolumn{1}{c}{ FAMILI BIVALVIA } & INDEKS MORISITA & KETERANGAN \\
\hline 1 & Famili Archidae & 1,092 & Berkelompok \\
2 & Famili Cardidae & 10 & Berkelompok \\
3 & Famili Donacidae & 2,141 & Berkelompok \\
4 & Famili Myidae & 3,565 & Berkelompok \\
5 & Famili Mytilidae & 7,212 & Berkelompok \\
6 & Famili Pteriidae & 3,868 & Berkelompok \\
7 & Famili Tellinidae & 1,500 & Berkelompok \\
8 & Famili Tridacnidae & 10 & Berkelompok \\
9 & Famili Veneridae & 3,146 & Berkelompok \\
\hline
\end{tabular}

Perbandingan dilakukan terhadap total populasi bivalvia di Stasiun 1 (Tg. Momong) dan Stasiun 2 (Pulau Termawan), serta terhadap jumlah jenis/spesies bivalvia di Stasiun 1 dan Stasiun 2. Perbandingan antara Stasiun 1 dan Stasiun 2 dilakukan karena substrat dasar perairan di kedua perairan tersebut sama-sama berpasir, yang membedakan adalah posisi perairannya; Stasiun $1 \mathrm{Tg}$. Momong berada di perairan terbuka sedangkan Stasiun 2 Pulau Termawan berada di perairan tertutup, dengan demikian perbandingan dilakukan untuk mengetahui apakah kondisi perairan terbuka dan tertutup mempengaruhi total populasi dan jumlah jenis bivalvia yang dapat ditemukan. Sebelum dilakukan perbandingan, terlebih dahulu dilakukan Uji Pola Distribusi Data, apabila data tersebar normal maka perbandingan dilakukan secara Statistika Parameterik (dengan Uji T) namun apabila data tidak tersebar normal maka perbandingan dilakukan secara Statistika NonParametrik (dengan Uji Mann-Whitney). Dari grafik pada Gambar 6 dapat dilihat bahwa data tersebar normal, dengan demikian uji perbandingan bisa dilakukan secara Statistika Parameterik dengan Uji T. 

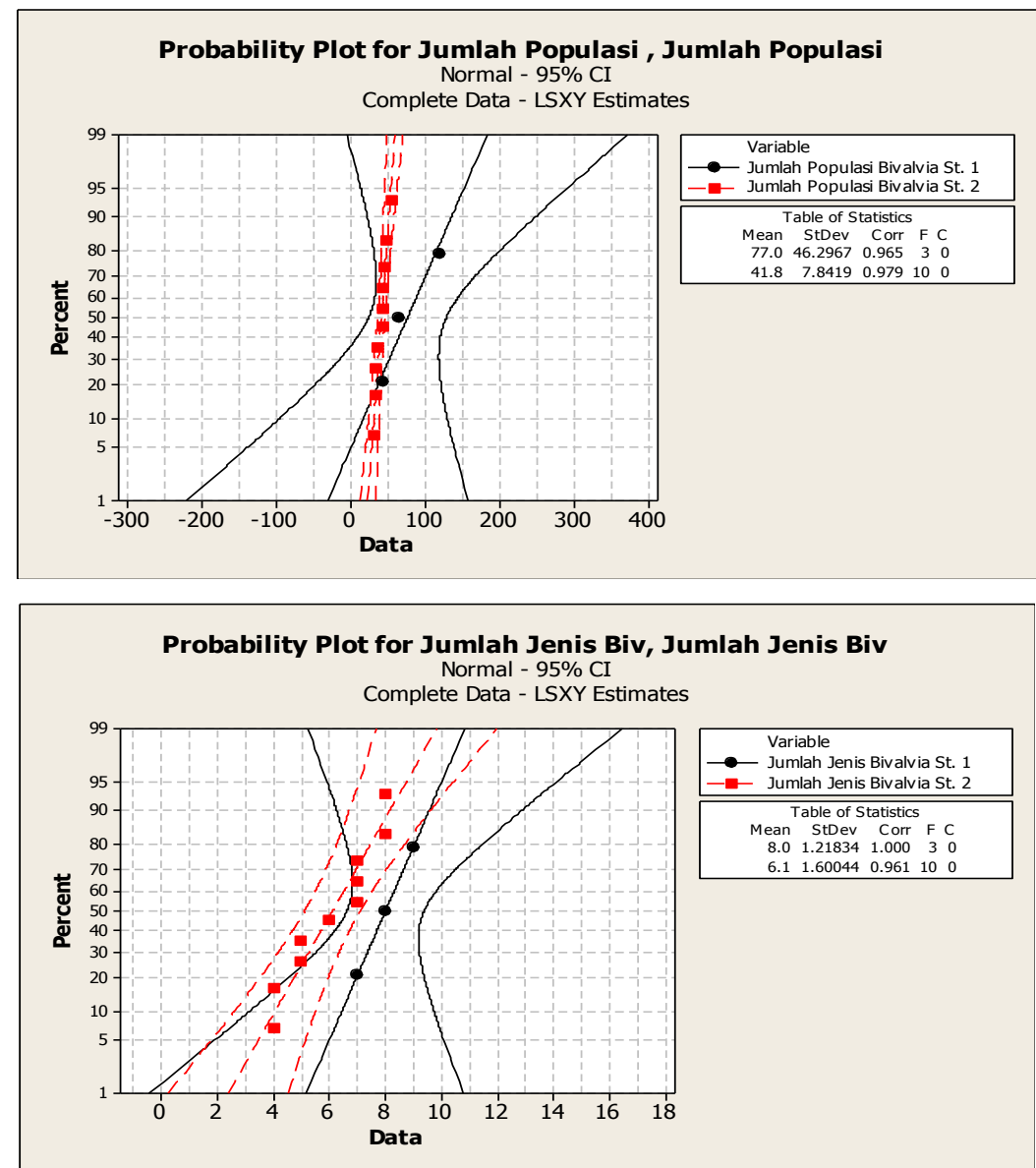

Gambar 6. Hasil Uji Normalitas Data (atas: variabel jumlah populasi bivalvia; bawah: variabel jumlah jenis bivalvia)

Hasil Uji T disajikan pada Tabel 6 dan 7. Pada Tabel 6 dapat dilihat bahwa P-Value kurang dari 0,05, dengan demikian dapat disimpulkan bahwa jumlah total populasi bivalvia di St. 1 dan St. 2 tidaklah sama pada tingkat signifikansi 95\%. Pada Tabel 7 dapat dilihat bahwa P-Value lebih dari 0,05 namun lebih kecil dari 0,1, dengan demikian dapat disimpulkan bahwa jumlah jenis/spesies bivalvia antara St. 1 dan St. 2 adalah sama pada tingkat signifikansi 95\%, namun dapat dikatakan sama pada tingkat signifikansi $90 \%$. Grafik boxplot hasil perbandingan data Stasiun $1 \mathrm{Tg}$. Momong dan Stasiun 2 Pulau Termawan disajikan pada Gambar 7. Dari grafik tersebut dapat dilihat bahwa Stasiun $1 \mathrm{Tg}$. Momong memiliki rata-rata jumlah populasi bivalvia dan jumlah spesies bivalvia lebih tinggi daripada Stasiun 2 Pulau Termawan. Lokasi perairan yang berada di perairan terbuka diperkirakan menjadi salah satu penyebab tingginya populasi dan jumlah jenis bivalvia di Stasiun 1 Tg. Momong; dengan kondisi perairan yang terbuka, maka 
memperbesar kemungkinan masuknya larva bivalvia bersama arus laut dari perairan lainnya.
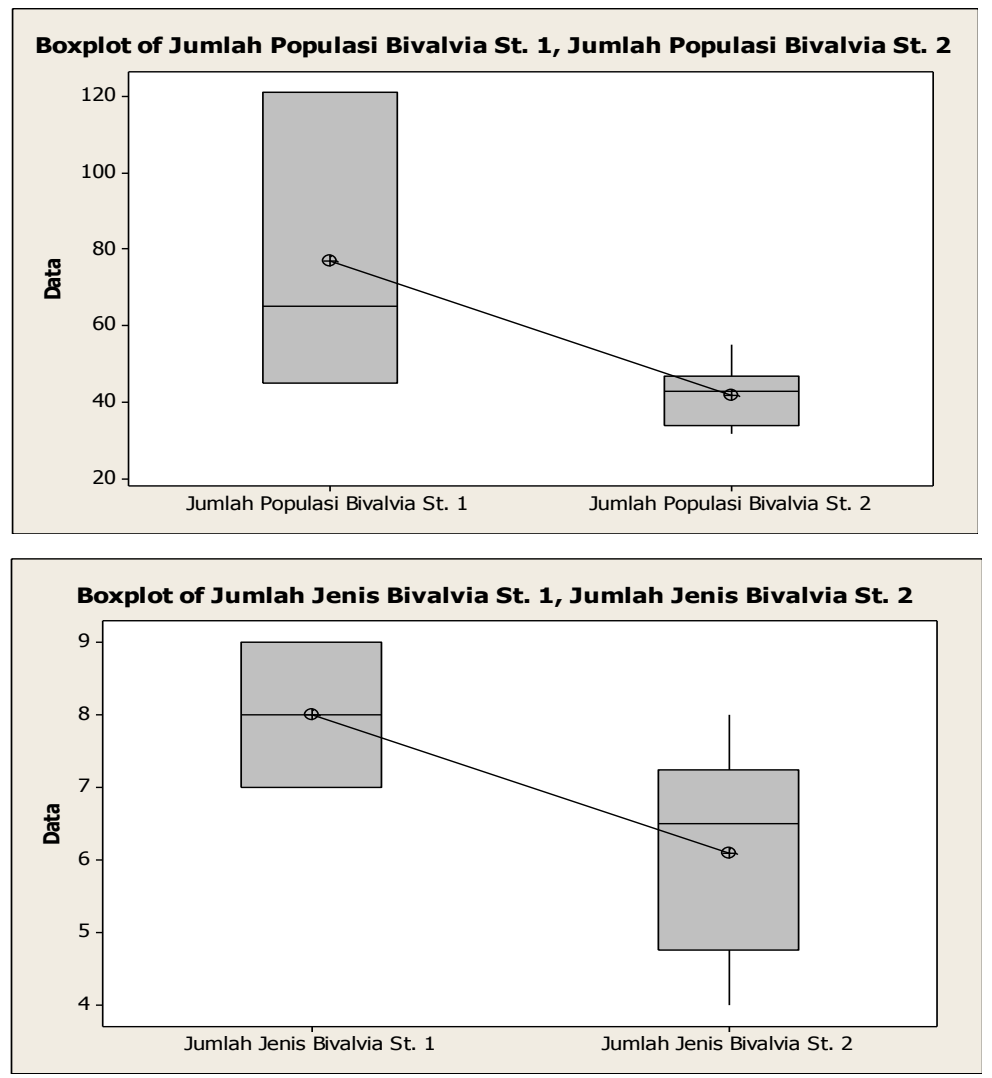

Gambar 7. Boxplot Hasil Perbandingan Data Stasiun 1 Tg. Momong dan Stasiun 2 Pulau Termawan (atas: variabel jumlah populasi bivalvia; bawah: variabel jumlah jenis bivalvia)

\section{KESIMPULAN}

Bivalvia yang ditemukan di perairan pesisir Pulau Siantan Kabupaten Kepulauan Anambas terdiri dari 13 famili dan 24 spesies. Jenis spesies yang sama-sama diketemukan pada keempat stasiun yaitu: Anadara granosa, Anadara notifera, Tellina disculus, dan Tridacna crocea. Indeks keanekaragaman jenis (H') Bivalvia di lokasi penelitian berkisar antara 2,359 hingga 3,314 atau berkisar sedang hingga tinggi, namun 3 dari 4 lokasi sampling menunjukkan Indeks keanekaragaman jenis yang tinggi.

Indeks keseragaman jenis (E) berkisar antara 0,682 - 0,832 sehingga dapat dikatakan bahwa tingkat keseragamannya tinggi. Indeks dominansi jenis (D) berkisar antara 0,154 - 0,262 sehingga dapat dikatakan bahwa tingkat dominansi rendah. Dengan tingkat keanekaragaman jenis yang cenderung tinggi, tingkat keseragaman jenis rendah, 
dan tingkat dominansi jenis tinggi, maka dapat dikatakan bahwa struktur komunitas Bivalvia di lokasi studi tergolong stabil.

Hasil analisis pola distribusi dengan Indeks Morisita menunjukkan bahwa semua family Bivalvia mempunyai pola distribusi berkelompok. Hasil analisis Uji-T memberikan hasil bahwa terdapat perbedaan antara jumlah total populasi bivalvia di Pantai Berpasir Tg. Momong dan Pantai Berpasir Pulau Termawan (P-Value < 0,05); dan juga terdapat perbedaan antara jumlah spesies di Pantai Berpasir Tg. Momong dan Pantai Berpasir Pulau Termawan $(\mathrm{P}-$ Value $<0,1)$. Lokasi perairan yang berada di perairan terbuka diperkirakan menjadi salah satu penyebab tingginya populasi dan jumlah jenis bivalvia di Stasiun $1 \mathrm{Tg}$. Momong; dengan kondisi perairan yang terbuka, maka memperbesar kemungkinan masuknya larva bivalvia bersama arus laut dari perairan lainnya.

\section{REFERENSI}

Seashell. http://seashellhub.com [4 Mei 2012].

Fachrul, F. M. 2008. Metode Sampling Bioekologi. Penerbit Bumi Aksara. Jakarta.

Fiene-Severn, P., M. Severn, dan R. Dyerly. 2000. Periplus Nature Guides of Tropical Seashells. Periplus Edition (HK) Ltd. Singapore.

Iriawan, N. dan S.P. Astuti. 2006. Mengolah Data Statistik denan Mudah Menggunakan MINITAB Ver. 14. CV Andi Offset. Yogyakarta.

Nontji, A. 2007. Laut Nusantara. Penerbit Djambatan. Jakarta.

Nybakken, J. W. 1992. Biologi Laut: Suatu Pendekatan Ekologis, alih bahasa oleh H. M. Eidman. Penerbit Gramedia. Jakarta.

Romimohtarto, K. dan S. Juwana. 2007. Biologi Laut: Ilmu Pengetahuan tentang Biota Laut. Penerbit Djambatan. Jakarta.

Sabelli, B. 1991. The MacDonalds Encyclopedia of Shells. MacDonalds \& Co. Publisher. Inggris.

Sitorus BR., D. 2008. Keanekaragaman dan Distribusi Bivalvia serta Kaitannya dengan Faktor Fisika-Kimia di Perairan Pantai Labu Kabupaten Deli Serdang [Thesis]. Sekolah Pasca Sarjana Program Studi Biologi - Universitas Sumatera Utara (USU). Medan.

Suwignyo, S., B. Widigdo, Y. Wardiatno, dan M. Kristanti. 2005. Avertebrata Air, Jili 1. Penebar Swadaya. Jakarta. 